\title{
STRATEGI KOMUNIKASI PEMASARAN TERPADU EKOWISATA DI KEBUN RAYA EKA KARYA, BEDUGUL, BALI
}

\author{
Muntadliroh \\ UPT Balai Konservasi Tumbuhan Kebun Raya Eka Karya Bali-LIPI \\ Email: mun_tadliroh@yahoo.com
}

\begin{abstract}
Ecotourism of Bali Botanical Garden, Bedugul, Tabanana Regency, Bali, has been able to increase the number of visitors from time to time though it is still far from the optimum level. In 2010-2011 the number of visitors at Bali Botanical Gardens was counted for 368.927 people. Based on the data, visitors interest to visit Bali Botanical Garden are still low. Facing this problem, integrated marketing communication strategy is needed. This paper discusses implementation of integrated marketing communication concept created by Philip Kotler to the market ecotourism at Bali Botanical Garden, by using case study for qualitative research. The results of this analysis show that implementing this concept made a better relationship between Bali Botanical Garden and its visitors, also increasing quantity of its visitors.
\end{abstract}

Keywords: Bali Botanical Garden, Ecotourism, Integrated Marketing Communications

\section{Pendahuluan}

Pariwisata merupakan salah satu industri yang berkembang sangat cepat dan menjadi sumber pendapatan bagi banyak negara. Pariwisata juga membantu merevitalisasi ekonomi lokal dengan menyediakan banyak kesempatan lapangan kerja. Meski demikian, seperti halnya pembangunan, pariwisata juga dapat menimbulkan banyak permasalahan, seperti ketimpangan sosial, kehilangan warisan budaya, ketergantungan ekonomi, dan kerusakan ekologi. Belajar dari kondisi ini, wisatawan mulai mencari liburan yang lebih bertanggung jawab, termasuk didalamnya adalah wisata yang berkelanjutan, seperti wisata alam, ekowisata, dan wisata budaya.

Definisi ekowisata yang pertama diperkenalkan oleh organisasi The International Ecotourism Society (Elperwood 1990) sebagai suatu bentuk perjalanan wisata ke area alami yang dilakukan dengan tujuan mengonservasi lingkungan dan melestarikan kehidupan dan kesejahteraan penduduk setempat. Semula ekowisata dilakukan oleh wisatawan pecinta alam yang menginginkan di daerah tujuan wisata tetap utuh dan lestari, serta budaya dan kesejahteraan masyarakatnya tetap terjaga. Namun, bentuk ekowisata 
ini berkembang karena banyak digemari oleh wisatawan. Wisatawan ingin berkunjung ke area alami, yang dapat menciptakan kegiatan bisnis. Ekowisata kemudian didefinisikan sebagai bentuk baru dari perjalanan bertanggung jawab ke area alami dan berpetualang yang dapat menciptakan industri pariwisata.

Salah satu objek wisata di Bali yang menawarkan konsep ekowisata adalah Kebun Raya Eka Karya Bali, terletak 50 km utara Denpasar. Kebun Raya Eka Karya Bali merupakan tempat yang unik di Pulau Bali yang memadukan penelitian botani, pelestarian tumbuhan, pendidikan, dan rekreasi. Di sini pengunjung dapat bersantai sambil menikmati keindahan alam dan mempelajari manfaat tumbuhan bagi kehidupan masyarakat. Statusnya saat ini adalah Unit Pelaksana Teknis Balai Konservasi Tumbuhan Kebun Raya Eka Karya Bali (SK Kepala Lembaga Ilmu Pengetahuan Indonesia No. 1019/M/2002, tanggal 12 Juni 2002) dan Kawasan dengan Tujuan Khusus sebagai Hutan Pendidikan dan Penelitian bagi peruntukan Kebun Raya Eka Karya Bali (SK Menteri Kehutanan No. 252/Kpts-II/2003, tanggal 28 Juli 2003).

Kebun Raya Bali yang berdiri sejak 15 Juli 1959 tersebut sudah selayaknya dikenal masyarakat. Namun kenyataannya, dalam kurun waktu 2010-2011 jumlah kunjungan wisatawan ke Kebun Raya Bali masih rendah, yaitu di bawah 350.00o orang per tahun. Angka ini hanya mencakup 60-80\% dari target yang ditetapkan dalam Rencana Kerja Tahunan Kebun Raya Eka Karya Bali (Tabel 1).

Tabel 1. Jumlah kunjungan wisatawan di Kebun Raya Eka Karya Bali tahun 20102015

\begin{tabular}{cccc}
\hline Tahun & Realisasi & Target & Persentase \\
\hline 2010 & 343.920 & 499400 & $68.87 \%$ \\
2011 & 368.927 & 460 ooo & $80.21 \%$ \\
2012 & 369.770 & 623424 & $59.31 \%$ \\
2013 & 395.743 & 570793 & $69.33 \%$ \\
2014 & 477.955 & 397 ooo & $120.39 \%$ \\
2015 & 509.318 & 408 ooo & $124.83 \%$ \\
\hline
\end{tabular}

Sumber: Laporan Tahunan Kebun Raya Eka Karya Bali-LIPI

Karena itu, Kebun Raya Bali menerapkan pemasaran ekowisata dengan metode yang lebih efektif untuk mendongkrak angka kunjungan. Kebun Raya Bali perlu mengemas potensi ekowisata yang dimilikinya dalam media penyampai pesan yang efektif. Di samping pemilihan media, dalam proses penyampaian pesan tersebut pun pengelola perlu memilih pendekatan pemasaran yang mampu menjangkau sasaran yang tepat karena semua pendekatan ini akan bermuara pada peningkatan jumlah kunjungan wisata 
di Kebun Raya Bali. Oleh karena itu, Komunikasi Pemasaran Terpadu (Integrated Marketing Communications) merupakan salah satu pendekatan yang dapat diaplikasikan dalam pengembangan ekowisata di Kebun Raya Bali.

Penelitian tentang pemasaran ekowisata telah banyak dibahas oleh penelitian sebelumnya, salah satunya oleh Hendarto (2003) tentang Bauran Pemasaran pada Jasa Ekowisata menggunakan pendekatan bauran pemasaran klasik Mc Carthy (1981) yang terdiri atas empat variabel, yaitu product (produk), price (harga), place (tempat), dan promotion (promosi). Namun, penelitian Hendarto (2003) hanya mendeskripsikan masing-masing unsur bauran tanpa menjelaskan efek bauran pemasaran terhadap segmen pasar yang dipilih.

Tulisan ini membahas pengembangan ekowisata menggunakan pendekatan Komunikasi Pemasaran Terpadu Philip Kotler yang menekankan pada dampak setiap elemennya terhadap target market, sehingga tercipta pola yang ideal untuk mengembangkan ekowisata yang pada akhirnya akan mengarah pada peningkatan jumlah kunjungan wisatawan ke Kebun Raya Bali.

\section{Metode Penelitian}

Penelitian ini menggunakan metode pendekatan kualitatif. Moleong (2007) mendefinisikan metode kualitatif sebagai prosedur penelitian yang menghasilkan data deskriptif berupa kata-kata tertulis atau lisan dari orangorang atau perilaku yang diamati. Muhadjir (2002), menegaskan bahwa metode kualitatif lebih diutamakan dalam pandangan naturalistik karena lebih manusiawi dalam memandang objek penelitian berupa individu atau sekelompok individu sebagai realitas yang dinamis, progresif, dan kreatif. Penelitian kualitatif dipilih dengan tujuan dapat lebih memahami dari penyelidikan yang mendalam terhadap fokus permasalahan yang diamati.

Peneliti mengumpulkan data dan fakta di lapangan terkait implementasi strategi komunikasi pemasaran terpadu dan dampaknya pada peningkatan jumlah wisatawan yang mengunjungi Kebun Raya Eka Karya Bali. Peneliti melihat objek penelitian sebagai individu ataupun kelompok individu yang memiliki pola pemikiran mendalam yang mampu menjawab masalah penelitian. Data dipaparkan dalam bentuk analisis kata-kata.

Penelitian ini menggunakan tipe studi kasus deskriptif (Yin 2008), di mana penelitian dilakukan secara mendalam dan detail mengenai unsur komunikasi pemasaran terpadu yang dilaksanakan oleh Kebun Raya Eka Karya Bali beserta dampak dan efektifitas pelaksanaannya. Pengumpulan data dilakukan dengan observasi dan wawancara mendalam dengan pihak pengelola ekowisata di Kebun Raya Eka Karya Bali.

Keunikan kasus merupakan salah satu aspek penting dari sebuah 
penelitian yang menggunakan metode studi kasus. Salim (2006) mengatakan bahwa keunikan dari kasus pada umumnya berkaitan dengan hakikat kasus tersebut, latar belakang histories, setting fisik, konteks kasus (khususnya ekonomi, politik, hukum dan estetika), kasus-kasus lain dari sekitar yang dipelajari dari informan atau pemberi informasi tentang keberadaan kasus tersebut.

Implementasi strategi komunikasi pemasaran terpadu pada jasa ekowisata di Kebun Raya Eka Karya Bali layak dikaji menggunakan analisis studi kasus karena memiliki sisi keunikan tersendiri. Kebun Raya Eka Karya Bali yang pada tahun 2016 berusia 57 tahun sudah seharusnya dikenal luas oleh masyarakat. Letak geografisnya yang berada di pulau Bali sebagai daerah tujuan wisata internasional, tidak menutup kemungkinan bagi Kebun Raya Eka Karya Bali dapat dikunjungi banyak wisatawan domestik maupun mancanegara. Kebun Raya Eka Karya Bali sebagai salah satu lembaga pemerintah dengan anggaran terbatas berinisiatif untuk mengimplementasikan strategi komunikasi pemasaran terpadu untuk mendongkrak minat kunjungan wisatawan ke Kebun Raya Eka Karya Bali. Oleh karenanya, diperlukan kreativitas dan perencanaan yang baik dalam memilih dan mengimplementasikan strategi komunikasi pemasaran jasa ekowisatanya.

Disamping itu, keunikan dari implementasi strategi komunikasi pemasaran terpadu di Kebun Raya Eka Karya Bali adalah tidak hanya berorientasi pada tujuan profit, melainkan ada tanggung jawab edukasi akan pentingnya konservasi lingkungan pada publik yang menjadi sasarannya.

\section{Konsep Komunikasi Pemasaran Terpadu}

Komunikasi Pemasaran Terpadu (Integrated Marketing Communications atau IMC) sudah mulai dikenal sejak tahun 1980-an. IMC adalah sebuah proses bisnis yang memanfaatkan berbagai media untuk berkomunikasi. Dengan banyaknya event sport, kehadiran internet dan mobile, call center, dan lain-lain, menjadikan perhatian terhadap IMC semakin kuat (Marketing. co.id).

Para pemilik merek, akhirnya harus melakukan perubahan orientasi dalam berkomunikasi. Kini komunikasi bukan hanya diperlukan dalam tahap akuisisi, atau mendapatkan pelanggan baru. Komunikasi juga diperlukan untuk membangun hubungan jangka panjang, dan hal ini tidak terbatas pada media tradisional semata. Marketer kini harus semakin memahami customer touch point dan berkomunikasi efektif dengan pelanggan sesuai dengan touch point.

Menurut Four As (The American Association of Advertising Agency), IMC adalah Konsep perencanaan komunikasi pemasaran yang mengakui nilai tambah rencana komprehensif yang mengkaji pesan strategis masing- 
masing bentuk komunikasi - misalnya iklan, direct respone, promosi penjualan, serta public relations - dan memadukannya untuk meraih kejelasan konsistensi, dan dampak komunikasi maksimal melalui pengintegrasian pesan (Shimp 2012).

Dari definisi tersebut dapat dirumuskan fungsi utama dari komunikasi pemasaran adalah memfasilitasi hubungan yang saling menguntungkan antara perusahaan dengan konsumen. Philip Kotler (2009) mengklasifikasikan bauran komunikasi pemasaran ke dalam lima cara komunikasi utama yaitu, Periklanan, Promosi Penjualan, Hubungan Masyarakat, Penjualan perseorangan, dan Pemasaran langsung.

Tabel 2. Komponen Bauran Komunikasi Pemasaran Philip Kotler 2009

\begin{tabular}{|c|c|c|c|c|}
\hline Periklanan & $\begin{array}{c}\text { Promosi } \\
\text { Penjualan }\end{array}$ & $\begin{array}{l}\text { Hubungan } \\
\text { Masyarakat }\end{array}$ & $\begin{array}{l}\text { Penjualan } \\
\text { Pribadi }\end{array}$ & $\begin{array}{c}\text { Pemasaran } \\
\text { Langsung }\end{array}$ \\
\hline $\begin{array}{l}\text { - Iklan cetak } \\
\text { - Brosur atau buku } \\
\text { petunjuk } \\
\text { - Billboard } \\
\text { - Materi audio } \\
\text { visual }\end{array}$ & $\begin{array}{l}\text { - Pemberian } \\
\text { a contoh produk } \\
\text { - Pameran } \\
\text { - Rabat }\end{array}$ & $\begin{array}{l}\text { - Penyusunan } \\
\text { materi berita } \\
\text { - Seminar } \\
\text { - Laporan tahunan } \\
\text { - Sumbangan amal } \\
\text { - Publikasi }\end{array}$ & $\begin{array}{l}\text { - Pemberian } \\
\text { sample } \\
\text { - Pekan raya dan } \\
\text { pameran dagang } \\
\text { l }\end{array}$ & $\begin{array}{l}\text { - Surat } \\
\text { - Pemasaran } \\
\text { melalui telepon } \\
\text { - Fax mail } \\
\text { - E-mail }\end{array}$ \\
\hline
\end{tabular}

Sumber: Manajemen Pemasaran Philip Kotler 2009

Kebun Raya Bali perlu menyusun informasi mengenai pencitraan produk/jasa ekowisata dan lembaga Kebun Raya Bali itu sendiri, yang akan disampaikan kepada publik dengan memilih teknik komunikasi tertentu, dapat melalui kelima unsur komunikasi pemasaran tersebut (Gambar 1). Kelima unsur bauran komunikasi pemasaran tersebut saling terkait untuk mendukung pencapaian output dan outcome komunikasi seperti yang diharapkan oleh Kebun Raya Bali.

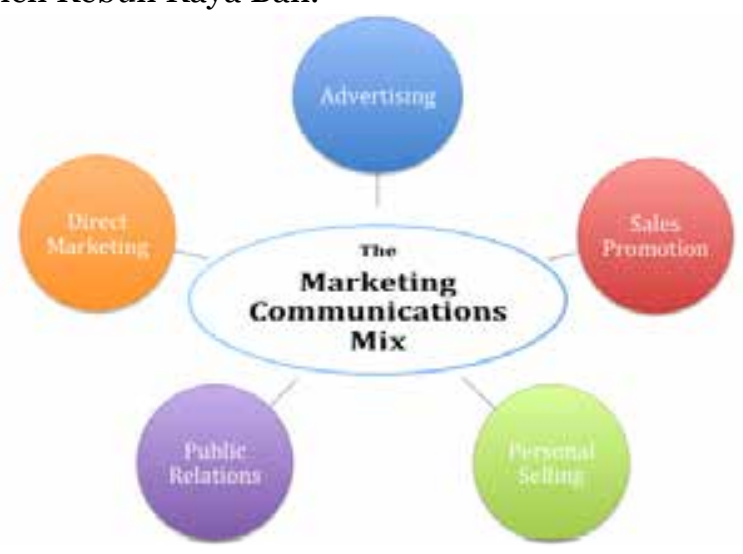

Gambar 1. Marketing Communications Mix Philip Kotler 2009. 


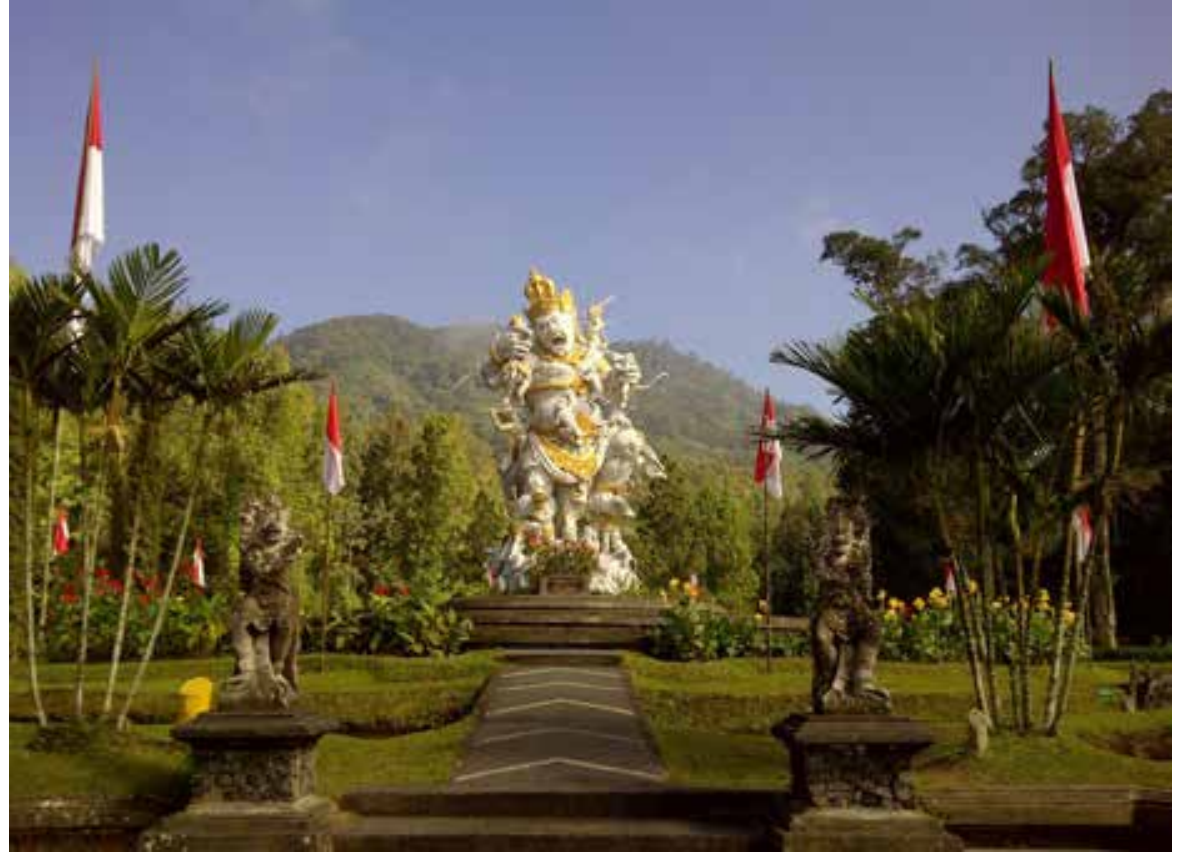

Foto 1. Pahatan Patung Kumbakarna Laga di tengah lansekap Kebun Raya Eka Karya Bali. Sumber: fanpage Kebun Raya Bali (Bali Botanic Garden) 2012.

Dari segi konseptual, Komunikasi Pemasaran Terpadu merupakan bagian dari konsep marketing secara umum dan bukan sekadar bagian dari Marketing Mix konvensional (4-Ps) Philip Kotler yang meliputi: Product, Price, Place, dan Promotions. Komunikasi Pemasaran Terpadu tidak hanya melingkupi elemen Marketing Mix yang terakhir saja (Promotions), tetapi juga merepresentasikan semua elemen Marketing Mix yang dimiliki Kebun Raya Bali, yang dikemas dalam setiap bauran komunikasi pemasaran untuk kemudian dikomunikasikan kepada publik. Komunikasi Pemasaran Terpadu (Integrated Marketing Communications) memfasilitasi terciptanya hubungan komunikasi yang baik antara Kebun Raya Bali dengan konsumennya.

Positioning ekowisata Kebun Raya Eka Karya Bali adalah "Konservasi dan Budaya dalam Harmoni.” Konsep yang diusung oleh Kebun Raya Bali berbeda dengan kebun raya lain di Indonesia. Kebun Raya Bali tidak hanya menjadi pusat konservasi tumbuhan, tetapi merupakan perpaduan hutan alam dan tradisi bali yang dekat dengan nilai budaya. Dengan kata lain, Kebun Raya Bali merupakan simbiosis dari situs purba, kearifan lokal, arsitektur, dan sastra lama (Foto 1).

\section{Konsep Ekowisata Kebun Raya Eka Karya Bali}

Kebun Raya Bali adalah salah satu objek wisata yang memenuhi kriteria Ekowisata. Menurut Masyarakat Ekowisata Indonesia atau MEI (1951) dalam Sembiring et.al (2004), kunci utama dari pemahaman tentang ekowisata dapat diuraikan ke dalam lima karakteristik, yang meliputi perjalanan yang bertanggung jawab untuk melakukan perlindungan alam dan budaya di lokasi objek wisata, lokasi ekowisata merupakan wilayah yang alami atau 
wilayah yang dikelola dengan mengacu pada kaidah alam, tujuan melakukan perjalanan ke objek ekowisata adalah menikmati pesona alam dan budaya, ekowisata mendukung konservasi alam dan budaya dengan tindakan nyata baik secara moral maupun materiil, dan meningkatkan kesejahteraan masyarakat di sekitar lokasi ekowisata (Sembiring 2004).

Kriteria ekowisata yang dimiliki Kebun Raya Bali dapat dijelaskan sebagai berikut:

1) Perjalanan yang bertanggung jawab yang diartikan sebagai upaya dari seluruh pihak yang terlibat dalam kegiatan ekowisata untuk melakukan perlindungan alam atau setidak-tidaknya meminimalkan pengaruh negatif terhadap lingkungan alam dan budaya di lokasi objek ekowisata.

Kebun Raya Eka Karya pada mulanya dikhususkan untuk mengoleksi Gymnospermae (tumbuhan berdaun jarum) dari seluruh dunia karena jenis-jenis ini dapat tumbuh dengan baik di dalam kebun raya. Namun, kemudian berkembang menjadi kawasan konservasi ex-situ tumbuhan pegunungan tropika Kawasan Timur Indonesia. Sesuai dengan misinya yaitu melestarikan, mendayagunakan dan mengembangkan potensi tumbuhan khususnya yang berasal dari Kawasan Timur Indonesia, melalui kegiatan konservasi, penelitian pendidikan serta peningkatan apresiasi masyarakat terhadap kebun raya, tumbuhan dan lingkungan dalam upaya pemanfaatan yang berkelanjutan untuk kesejahteraan masyarakat.

2) Lokasi ekowisata merupakan wilayah yang alami atau wilayah yang dikelola dengan mengacu pada kaidah alam seperti kawasan konservasi hutan (taman nasional, taman wisata alam, taman hutan rakyat, dan cagar alam) dan kawasan nonkonservasi (hutan adat) serta wilayah yang dikelola dengan kaidah alam (hutan wanagama, hutan produksi, taman hutan raya, dan cagar budaya. Kebun Raya Eka Karya Bali memiliki luas 157,5 Hektar dan terletak di lereng bukit pohen yang meliputi hutan reboisasi candikuning dan berbatasan dengan kawasan Cagar Alam Batukaru. Kebun Raya Bali berada di ketinggian 1.250 $1.450 \mathrm{~m}$ dpl dengan suhu berkisar antara $18-20^{\circ} \mathrm{C}$ dan kelembaban $70-90 \%$.

3) Tujuan melakukan perjalanan ke objek ekowisata adalah menikmati pesona alam, mendapatkan pengetahuan, dan meningkatkan pemahaman berbagai fenomena alam dan budaya. Sesuai dengan tugas pokok dan fungsi Kebun Raya Eka Karya Bali, selain sebagai tempat wisata yang mempunyai keindahan alam dan tata kelola tanaman koleksi yang indah, pengunjung juga dapat belajar menjelajah jalur konservasi yang memperkenalkan keragaman flora dan jalur budaya, serta menguraikan konsepsi budaya kearifan lokal Bali. 
4) Mendukung konservasi alam dan budaya dengan tindakan nyata, baik secara moral maupun materiil. Melalui kegiatan ekowisata akan diperoleh dana yang dapat digunakan untuk kelestarian alam, memberikan penghasilan kepada pelaku ekowisata, serta dapat mendukung pertumbuhan kegiatan dan usaha bagi masyarakat sekitarnya. Salah satu unit kegiatan yang dimiliki Kebun Raya Eka Karya Bali adalah Pembibitan dan Reintroduksi. Fungsi unit ini adalah memperbanyak jenis tanaman kategori langka di Kawasan Indonesia Timur yang pemanfaatannya untuk tujuan reboisasi, sosial, maupun komersial.

5) Meningkatkan kesejahteraan masyarakat di sekitar lokasi ekowisata melalui peningkatan peran masyarakat dalam penetapan perencanaan, pembangunan dan pengoperasiannya. Masyarakat berperan sebagai subjek yang akan mengubah paradigmanya terhadap alam dan kegiatan usaha yang berpeluang berkaitan dengan ekowisata. Dalam rangka membina hubungan baik dengan masyarakat sekitar, mayoritas sumber daya manusia yang mengelola Kebun Raya Eka Karya Bali berasal dari masyarakat lokal. Hal ini bertujuan menumbuhkan rasa memiliki kebun raya bagi masyarakat sekitar sehingga masyarakat merasa ikut menjadi bagian dari Kebun Raya Bali itu sendiri.

Di samping itu, Spillane (2001) menuliskan bahwa pada umumnya produk wisata mempunyai beberapa sifat khusus. (1) Produk wisata mempunyai ciri bahwa ia tidak dapat dipindahkan, dalam arti orang tak bisa membawa produk wisata pada langganan, tetapi langganan itu sendiri harus mengunjungi, mengalami, dan datang untuk menikmati produk wisata itu. (2) alam pariwisata, produksi dan konsumsi terjadi pada saat yang sama. Tanpa langganan yang sedang mempergunakan jasa-jasa itu, tidak akan terjadi kegiatan produksi wisata. (3) Sebagai suatu jasa, pariwisata memiliki berbagai ragam bentuk. Oleh karena itu, dalam bidang pariwisata tidak ada standar ukuran yang objektif, sebagaimana produk lain yang nyata, misalnya ada panjang, lebar, isi, kapasitas, dan sebagainya. (4) Langganan tidak dapat mencicipi produk itu sebelumnya dan bahkan tidak dapat mengetahui atau menguji produk itu sebelumnya. Pelanggan hanya dapat melihat brosur-brosur dan gambar-gambar. (5) Dari segi usaha, produk wisata merupakan usaha yang mengandung resiko besar. Industri wisata memerlukan penanaman modal yang besar, sedang permintaan sangat peka terhadap perubahan situasi ekonomi, politik, sikap masyarakat, atau kesenangan wisatawan, dan sebagainya. Perubahan-perubahan tersebut dapat menggoyahkan sendi-sendi penanaman modal usaha kepariwisataan karena bisa mengakibatkan kemunduran usaha yang deras, sedangkan sifat produk itu relatif lambat untuk menyesuaikan keadaan pasar.

Selain sisi positif, karakter bisnis pariwisata mempunyai kelemahan, 
yaitu rentan pada perubahan situasi politik, ekonomi, sosial, dan budaya. Faktanya industri pariwisata Bali kembali mendapat pukulan berat. Ledakan bom yang mengguncang Bali pada 1 Oktober 2005 di Kuta dan Jimbaran menurunkan target kunjungan wisatawan mancanegara (wisman) sebanyak 1,7 juta orang pada tahun 2005 tidak tercapai. Wisman yang berkunjung ke Bali sepanjang tahun 2005 hanya sebanyak 1,38 juta orang atau lebih rendah dibanding tahun 2004 sebanyak 1,46 juta orang (Evaluasi Debitur Pariwisata Pasca Bom Kuta dan Jimbaran, www.bi.go.id). Hal ini tentu berimbas pula pada kunjungan wisata di Kebun Raya Bali. Karenanya, diperlukan strategi komunikasi pemasaran yang efektif guna memaksimalkan jumlah kunjungan di tengah situasi politik, ekonomi, sosial, dan budaya yang tidak stabil.

Keunikan lain yang dimiliki Kebun Raya Bali adalah penataan tamannya yang konseptual. Taman Panca Yadnya misalnya, taman seluas 5,53 ha merupakan taman yang khusus mengoleksi tanaman yang biasa digunakan untuk bahan bangunan pura, hiasan pura, sesaji, dan upacara agama Hindu. Hal ini menunjukkan adanya harmoni yang tercipta antara Kebun Raya Bali dengan budaya Hindu. Kebun Raya Bali juga memiliki Taman Usadha, yaitu taman khusus tanaman obat. Hingga saat ini Taman Usadha telah mengoleksi 300 jenis tanaman yang berkhasiat obat dan biasa digunakan untuk pengobatan tradisional masyarakat Hindu Bali.

Di samping itu, penataan koleksi tanaman yang dimiliki Kebun Raya Bali dikelola ke dalam taman-taman tematik yang menarik (Foto 2 dan Foto 3). Di antaranya ialah taman anggrek, rumah kaca kaktus, taman aquatik, taman mawar, taman paku (ceathea), taman lumut dan lycophyte, taman bambu, dan rumah kaca begonia. Khusus untuk Begonia, Kebun Raya Bali merupakan satu-satunya Kebun Raya yang memiliki koleksi Begonia terlengkap di dunia. Terdapat sekitar 200 jenis Begonia telah dikoleksi di sini sehingga Kebun Raya Bali menjadi pusat koleksi dan pengembangan Begonia di Indonesia.

Selain keindahan tamannya, Kebun Raya Bali juga menyediakan wahana high rope bagi pengunjung yang tertarik berpetualang. Kebun Raya Bali juga memiliki program pendidikan lingkungan yang disusun dalam konsep jalur pemanduan. Pengunjung dapat menyewa pemandu dari Kebun Raya Bali atau dapat melakukan petualangan sendiri dengan mengikuti buku panduan yang ada. Jalur tracking ini secara garis besar terbagi dalam dua tema yaitu konservasi dan budaya. Tema tersebut kemudian diuraikan lagi menjadi lima rute perjalanan yang dapat dipilih oleh pengunjung, yaitu Jalur Kuning, Jalur Ungu, Jalur merah, Jalur Biru, dan Rute pengamatan Burung.

\section{Implementasi Komunikasi Pemasaran Terpadu di Kebun Raya}

Pada awal tahun 2012 Kebun Raya Bali mulai mengaplikasikan kelima unsur yang ada dalam bauran komunikasi pemasaran sebagai strategi yang 


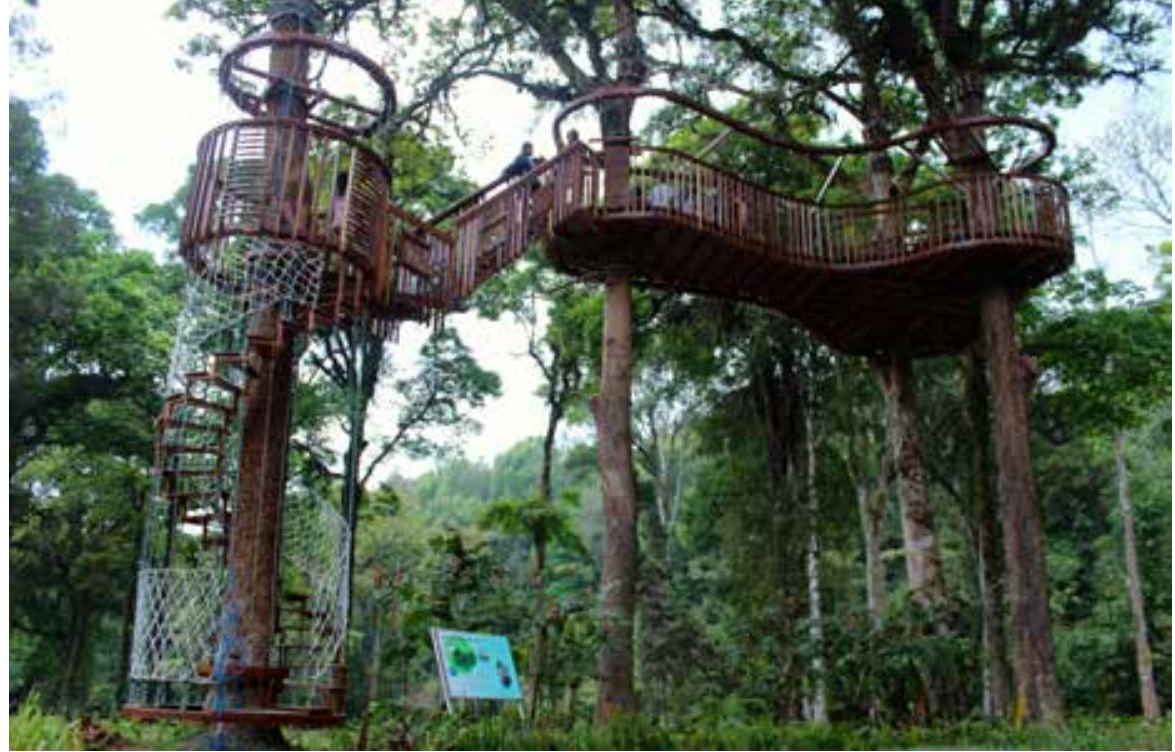

Foto 3. Anjungan Pengamatan Kanopi fasilitas pendukung bagi program pendidikan lingkungan hidup di Kebun Raya Eka Karya Bali, Sumber: dokumentasi Humas Kebun Raya Eka Karya Bali (2015).

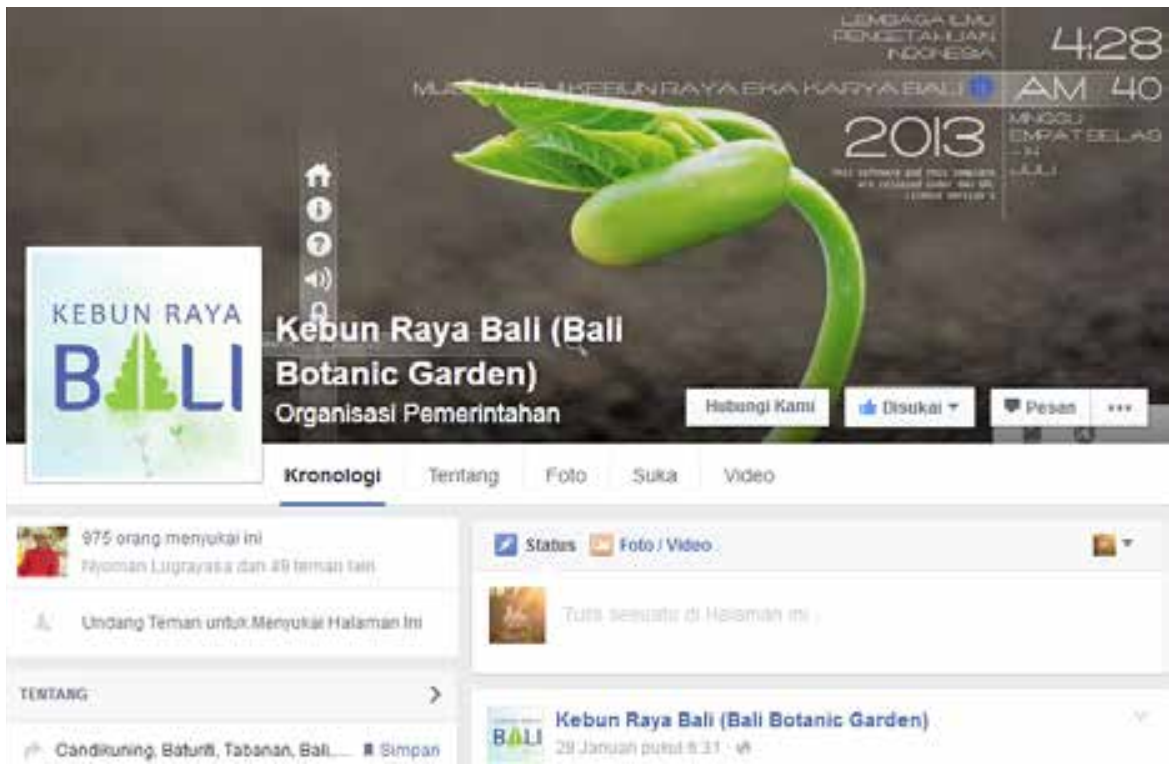

Foto 4. Tampilan fanpage Kebun Raya Bali (Bali Botanic Garden) di media sosial Facebook (2016).

memanfaatkan media sosial berupa fanpage Kebun Raya Bali (Bali Botanic Garden) di facebook dan website (Foto 4).

Selain itu, Di Gedung Informasi Kebun Raya Bali yang terletak berdekatan dengan pintu masuk dan loket tiket pun telah disediakan berbagai brosur koleksi tematik, brosur produk unggulan Kebun Raya Bali berupa Kompenit (Kompos Penambat Nitrogen), brosur fasilitas guest house Wijah Loka, convention hall Nayaka Loka, brosur peta Kebun Raya Bali, brosur jalur ekowisata, dan lain-lain (Foto 5). Pengunjung dapat mengambil brosur yang 


\section{Media Informasi \& Corporate Identity}

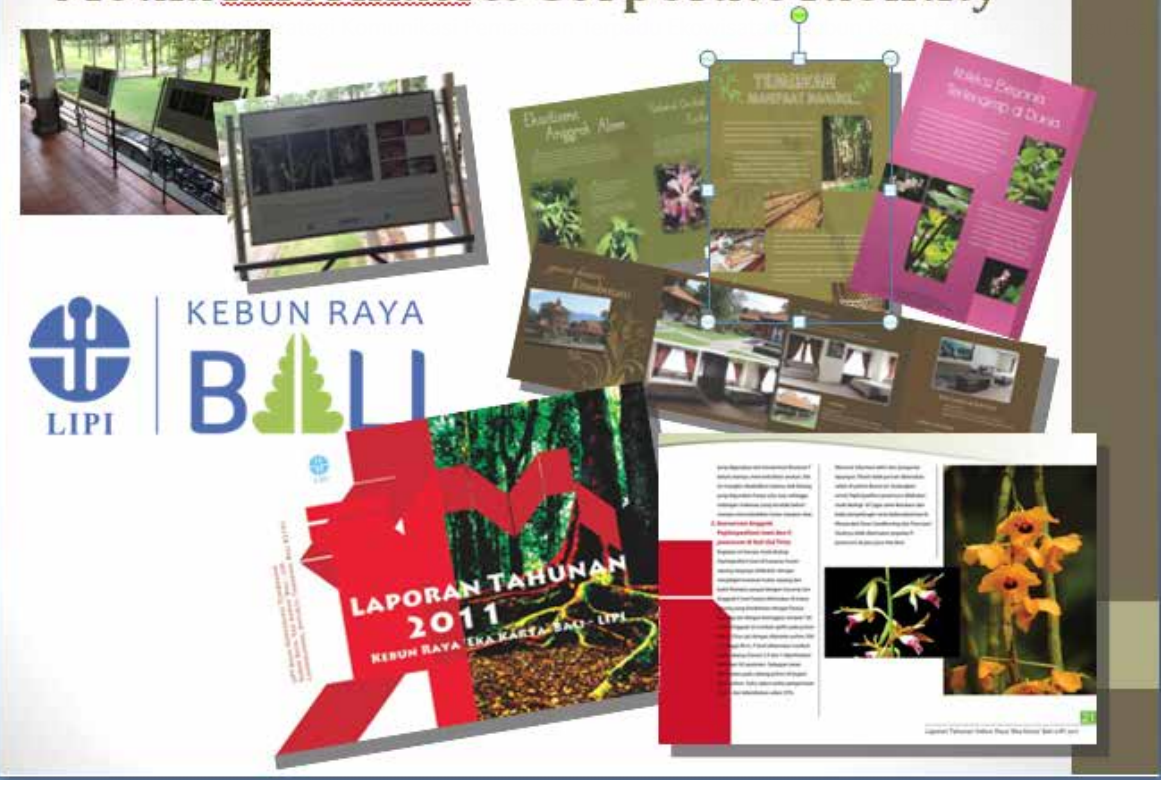

Foto 5. Media informasi publik berupa brosur fasilitas dan koleksi tumbuhan yang dimiliki Kebun Raya Eka Karya Bali, Sumber: Dokumentasi Humas Kebun Raya Eka Karya Bali (2015).

telah disediakan sebagai panduan yang akan memudahkan mereka dalam mengeksplorasi keindahan Kebun Raya Bali.

Dalam rangka menunjang program pendidikan lingkungan yang dicanangkan Kebun Raya Bali, kegiatan ini dilengkapi dengan fasilitas pendukung berupa materi audio visual. Film audio visual yang telah berhasil diproduksi Kebun Raya Bali antara lain ialah Film Profil Kebun Raya Bali untuk segmen siswa TK dan SD, Film Humus dan Kompenit untuk segmen siswa SMP, SMA dan Mahasiswa, Film Pembuatan Herbarium untuk siswa SMA dan Universitas. Materi audio visual ini dimanfaatkan untuk menunjang kegiatan pemanduan di Kebun Raya Eka Karya Bali sesuai permintaan dari sekolah atau pengunjung umum yang memerlukan informasi tersebut. Video tersebut juga dapat diakses publik melalui fanpage dan website Kebun Raya Eka Karya Bali.

\section{2) Promosi penjualan dengan tema konservasi dan produk ramah lingkungan}

Promosi penjualan menurut Kotler (2009) mencakup berbagai insentif jangka pendek untuk mendorong keinginan mencoba atau membeli suatu produk atau jasa. Dalam kaitannya dengan komunikasi pemasaran, promosi penjualan memberikan tiga manfaat sebagai proses komunikasi, insentif, dan ajakan.

Eleman promosi penjualan yang diimplementasikan oleh Kebun Raya Bali meliputi tiga unsur yaitu pemberian contoh produk, pameran, dan pemberian diskon. Pemberian contoh produk yang biasa dilakukan 
mencakup pemberian sampel produk unggulan Kebun Raya Bali, yaitu Kompos Penambat Nitrogen (Kompenit) kepada kelompok tani atau toko pertanian yang belum pernah menggunakan produk tersebut. Sampel produk yang ditawarkan tetap berorientasi pada konsep ekowisata Kebun Raya Eka Karya Bali yaitu berupa produk ramah lingkungan.

Promosi penjualan melalui pameran secara kontinu dilakukan Kebun Raya Bali, yang disesuaikan dengan tema dan tren kunjungan. Pada pertengahan tahun diselenggarakan pameran koleksi tumbuhan tematik atau dengan tema pendidikan lingkungan dengan sasaran siswa sekolah yang berkunjung ke Kebun Raya Eka Karya Bali.

Strategi promosi penjualan lainnya adalah dengan kebijakan pemberian diskon bagi grup siswa atau sekolah yang berkunjung ke Kebun Raya Bali sesuai dengan nota dinas dari Kepala Biro Perencana dan Keuangan LIPI, No: 23/ND/I/2013 peraturan tentang Dispensasi Pengenaan Tarif Masuk Pengunjung. Pemberian diskon ini efektif dalam mendorong minat kunjungan siswa ke Kebun Raya Eka Karya Bali, khususnya bagi pengunjung siswa (Tabel 3).

Tabel 3. Grafik jumlah pengunjung siswa di Kebun Raya Eka Karya Bali tahun 2012-2015.

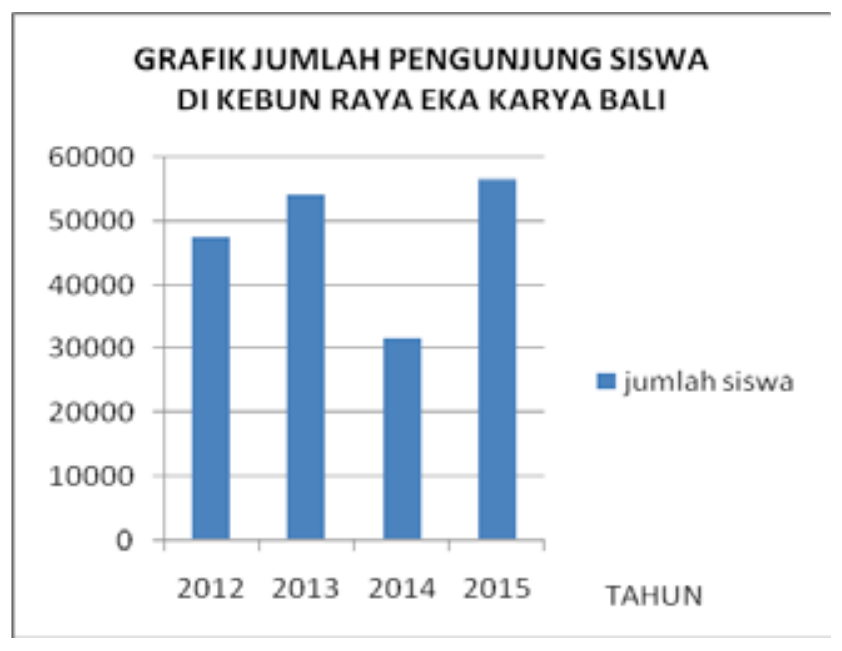

Sumber: Laporan tahunan Kebun Raya Eka Karya Bali.

Meskipun Kebun Raya Eka Karya Bali telah berupaya memberikan rabat khusus bagi pengunjung siswa, namun segmen ini memiliki memiliki karakter pengambilan keputusan yang unik. Dilihat dari rataan grafik kunjungan siswa di Kebun Raya Eka Karya Bali tahun 2012-2015, menunjukkan susunan grafik yang naik turun setiap tahunnya. Hal ini dipengaruhi oleh keputusan yang diambil pihak sekolah yang rata-rata memilih berkunjung 


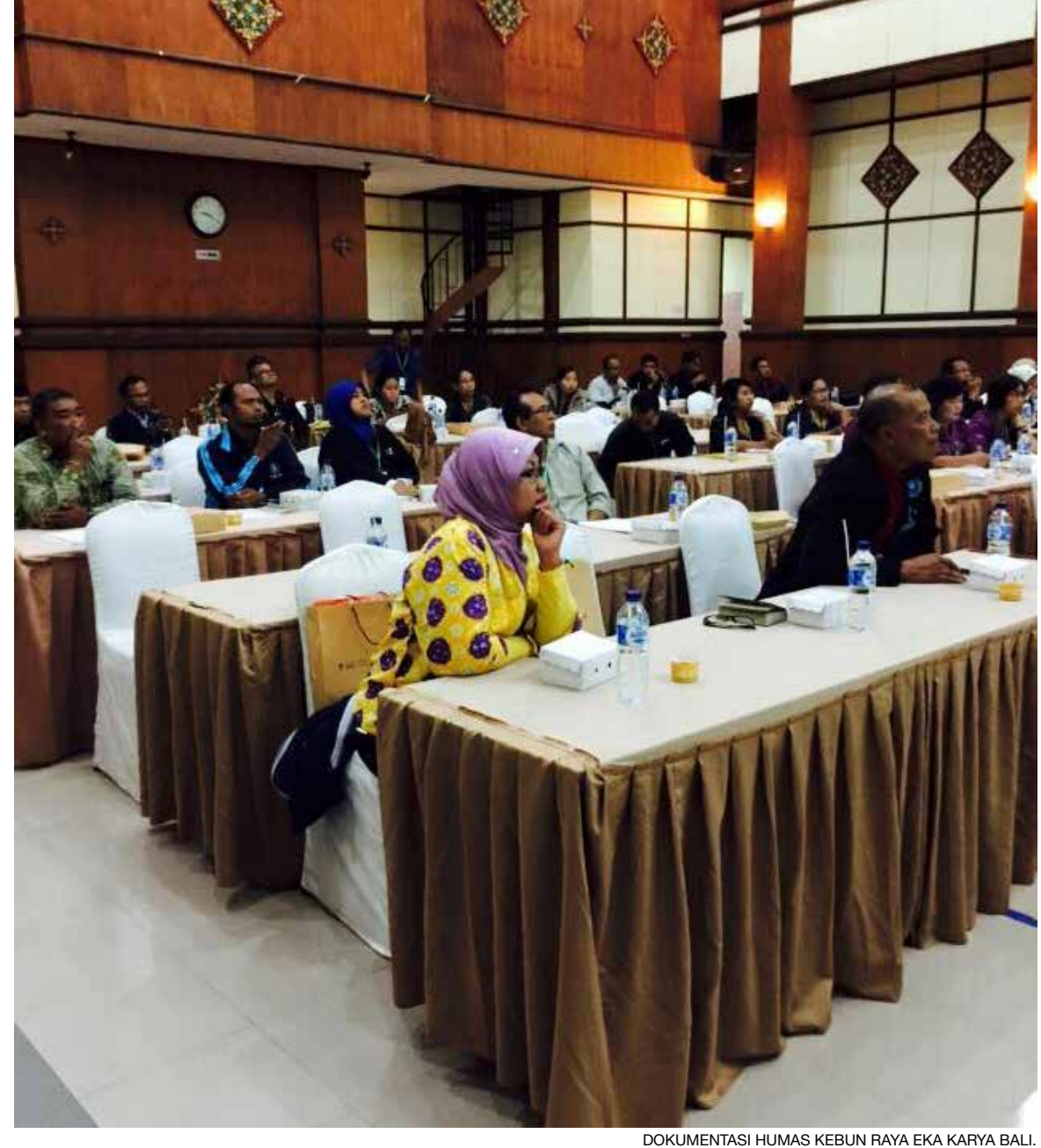

Foto 7. Workshop pendidikan lingkungan hidup di Kebun Raya Eka Karya Bali.

tahun 2015 Kebun Raya Eka Karya Bali juga menyelenggarakan workshop pendidikan lingkungan bagi para guru sekolah perintis program Adi Wityata dari kabupaten Badung, Gianyar, Tabanan, dan Buleleng Bali. Kegiatan workshop dan seminar semacam ini bertujuan membangun story telling pengetahuan perkebunrayaan bagi para stakeholder, sehingga diharapkan dapat menciptakan word of mouth atau cerita dari mulut ke mulut yang positif mengenai Kebun Raya Eka Karya Bali (Foto 7).

Pendekatan komunikasi kehumasan juga dilakukan dengan memberikan sumbangan bibit tanaman hasil perbanyakan di Kebun Raya Eka Karya Bali untuk kepentingan sosial kemasyarakatan. Pemberian sampel tanaman kepada calon pembeli bertujuan memberikan kesempatan uji coba ketahanan hidup tanaman tersebut di lokasi tanam calon pembeli (experiental marketing). Faktor perbedaan suhu di Kebun Raya Eka Karya Bali yang dingin dengan dataran rendah yang panas sangat berpengaruh terhadap daya tahan tanaman.

Kebun Raya Eka Karya Bali memiliki komitmen menyumbangkan 20\% 


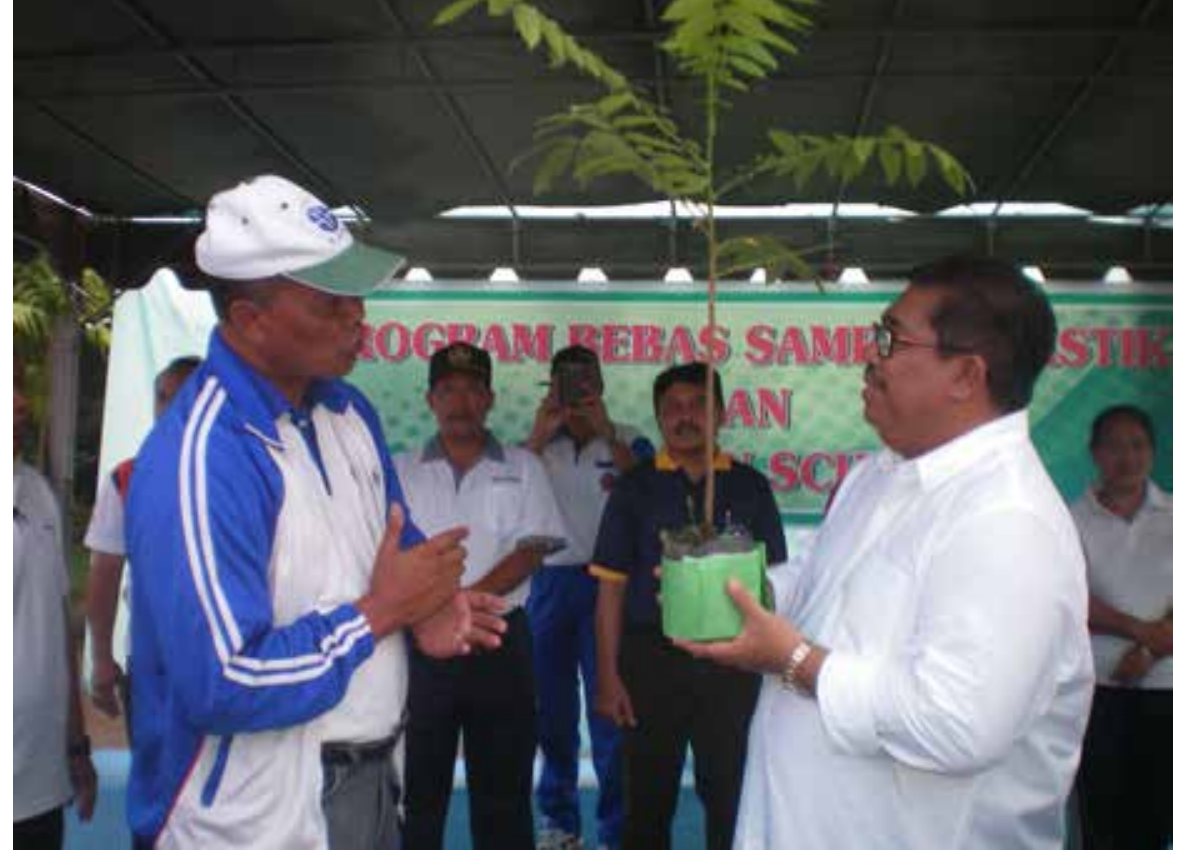

Foto 8. Penyerahan sumbangan bibit tumbuhan langka oleh Kepala Kebun Raya Eka Karya Bali (I Nyoman Lugrayasa) kepada Bupati Buleleng (Putu Agus Suradnyana) dan Kepala Dinas Pendidikan Kabupaten Buleleng (Wayan Lugraheni) pada acara penanaman pohon bersama tahun 2015. Sumber: Dokumentasi Humas Kebun Raya Eka Karya Bali.

dari total jumlah produksi perbanyakan tumbuhan langka setiap tahunnya untuk kepentingan sosial, baik bagi penghijauan Pura di wilayah Bali, disumbangkan pada desa adat, maupun untuk kepentingan penghijauan di sekolah-sekolah yang membutuhkan (Foto 8).

\section{Menyisipkan strategi penjualan pribadi dengan memberi sampel produk yang ramah lingkungan pada publik}

Penjualan Personal melibatkan interaksi langsung dengan satu calon pembeli atau lebih guna melakukan presentasi, menjawab pertanyaan dan menerima pesan. Penjualan personal menjadi alat yang efektif biaya pada tahap proses pembelian lebih lanjut, terutama dalam membangun preferensi, keyakinan, dan tindakan pembeli (Kotler:2009).

Bentuk komunikasi pemasaran yang dilakukan melalui pendekatan Penjualan Pribadi sama dengan pendekatan Promosi Penjualan, yaitu berupa pemberian sampel produk unggulan Kebun Raya Eka Karya Bali (Kompenit dan tanaman hasil perbanyakan) kepada calon pembeli dan penyelenggaraan pameran hasil litbang/pendidikan lingkungan (Foto 9).

\section{Melakukan strategi pemasaran langsung untuk menjangkau perhatian publik secara spesifik.}

Bentuk pemasaran langsung yang dilakukan Kebun Raya Eka Karya Bali berupa surat-menyurat kepada konsumen, telemarketing atau pemasaran melalui telepon, pemasaran melalui faximile dan email. Pendekatan 


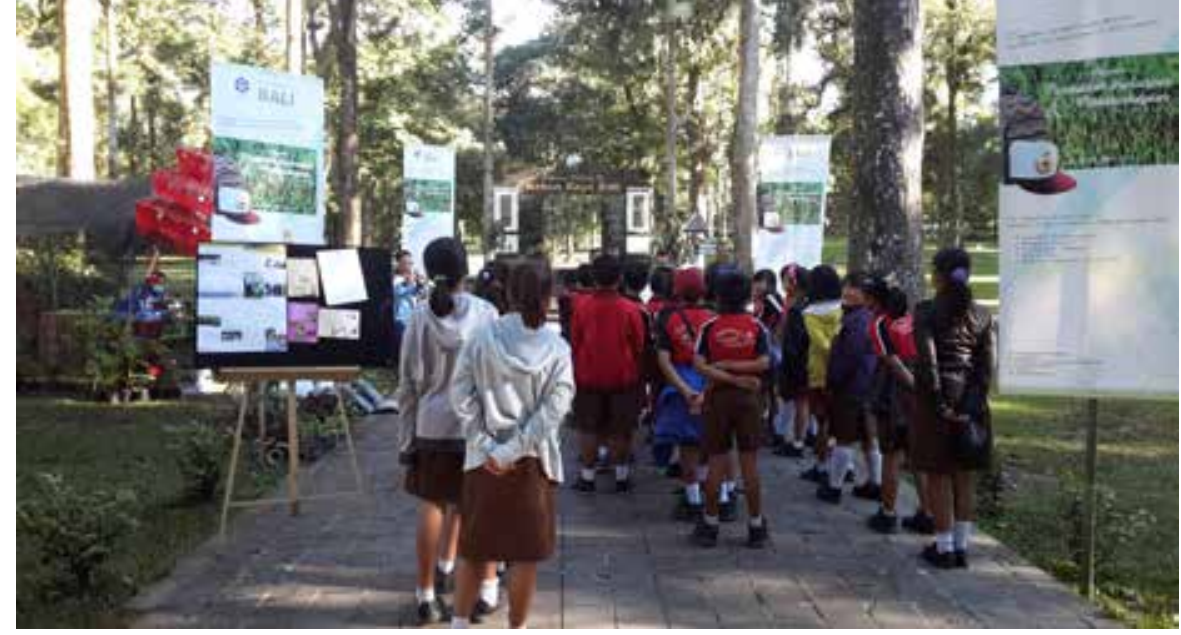

Foto 9. Pengunjung stand pameran pendidikan lingkungan hidup di Kebun Raya Eka Karya Bali tahun 2015. Sumber: Dokumentasi Humas Kebun Raya Eka Karya Bali.

komunikasi inilah yang paling sering dilakukan oleh Kebun Raya Eka Karya Bali dibanding pendekatan lain karena dalam pemasaran fasilitas dan lokasi, Kebun Raya Bali telah memiliki pelanggan tetap yang tercatat dalam data base. Untuk membina hubungan baik dengan para pelanggan tersebut, Kebun Raya Eka Karya Bali aktif membangun komunikasi dengan memberikan informasi terbaru apabila ada perubahan kebijakan, program diskon, kenaikan tarif, dan lain-lain. Dengan pemasaran langsung, pelanggan Kebun Raya Bali akan memperoleh pelayanan informasi yang up to date.

Kebun Raya Eka Karya Bali telah mengimplementasikan strategi komunikasi pemasaran terpadu sejak tahun 2012 melalui berbagai macam bentuk pendekatan dan kegiatan yang berbeda-beda sesuai dengan segmen publik yang menjadi sasaran dengan berpedoman pada tiap unsur bauran komunikasi pemasaran seperti yang dirumuskan oleh Philip Kotler. Dalam pelaksanaannya, dampak strategi komunikasi pemasaran terpadu yang dijalankan Kebun Raya Eka Karya Bali ini tidak langsung terlihat. Hal tersebut disebabkan beberapa pendekatan seperti kegiatan kehumasan, pameran, penjualan personal lebih menekankan pada upaya mendidik dan menumbuhkan pemahaman publik mengenai wawasan perkebunrayaan. Sehingga tidak berdampak langsung pada proses pembelian/pengambilan keputusan untuk berkunjung ke Kebun Raya Eka Karya Bali.

Salah satu kendala yang dihadapi dalam pelaksanaan komunikasi pemasaran terpadu di Kebun Raya Eka Karya Bali adalah keterbatasan anggaran promosi dan pemsaran. Namun hal ini tidak membatasi Kebun Raya Eka Karya Bali untuk memanfaatkan media promosi yang murah dan efektif seperti pembuatan fanpage Kebun Raya Bali (Bali Botanic Garden) yang memuat informasi perkebunrayaan bagi publik. Kebun Raya Eka Karya Bali juga konsisten dengan tugas pokok dan fungsinya sebagai lembaga konservasi tumbuhan langka. Tujuan konservasi tersebut disisipkan disemua pendekatan komunikasi pemasaran terpadu yang dijalankan, misalnya pameran yang diselenggarakan bertema hasil litbang dan koleksi tumbuhan 
langka, pemberian sumbangan bibit tumbuhan langka sebagai edukasi bagi siswa sekolah, memberikan diskon tiket masuk khusus rombongan sekolah disertai himbauan menjaga kebersihan Kebun Raya Eka Karya Bali, dan pemberian sampel produk pupuk Kompenit yang ramah lingkungan.

Berkat kosistensinnya pada tujuan konservasi lingkungan, maka pada tahun 2012-2015 grafik jumlah kunjungan wisatawan di Kebun Raya Eka Karya Bali menunjukkan peningkatan yang signifikan setiap tahunnya (Tabel 4). Hal ini menandakan bahwa implementasi strategi komunikasi pemasaran terpadu jasa ekowisata di Kebun Raya Eka Karya Bali telah dijalankan dengan efektif sehingga memberi dampak sesui dengan harapan pengelola.

Tabel 4. Jumlah Pengunjung Kebun Raya Eka Karya Bali Sebelum dan Sesudah Implementasi Komunikasi Pemasaran Terpadu

\section{GRAFIK JUMLAH PENGUNJUNG KEBUN RAYA EKA KARYA BALI}

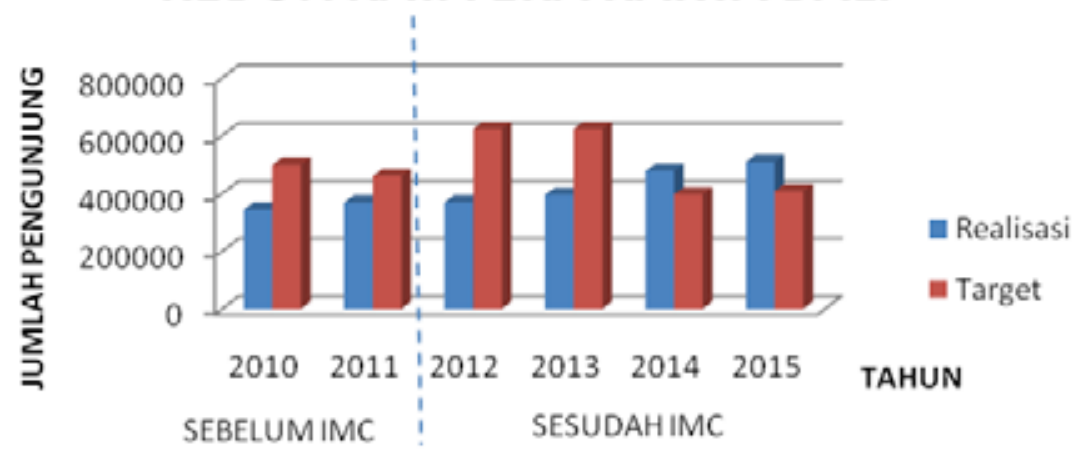

\section{Kesimpulan}

Pada tahun 2012 Kebun Raya Eka Karya Bali mulai menggunakan strategi komunikasi pemasaran terpadu (Integrated Marketing Communications) dalam memasarkan ekowisatanya kepada publik, melalui pendekatan periklanan, promosi penjualan, hubungan masyarakat, penjualan pribadi, dan pemasaran langsung.

Keunikan implementasi strategi Komunikasi Pemasaran Terpadu pada jasa ekowisata di Kebun Raya Eka Karya Bali adalah tidak hanya berorientasi pada profit peningkatan jumlah kunjungan wisata, namun juga mengedepankan tujuan komunikasi sosial berupa edukasi publik mengenai pentingnya menjaga kelestarian alam. Hal ini sesuai dengan tugas pokok dan fungsi Kebun Raya Eka Karya Bali sebagai lembaga konservasi tumbuhan langka Kawasan Timur Indonesia. 
Pendekatan periklanan, promosi penjualan, penjualan pribadi dan pemasaran langsung mempengaruhi pengambilan keputusan yang cepat bagi publik dalam memilih berkunjung atau pembelian produk Kebun Raya Eka Karya Bali. Pendekatan melalui hubungan masyarakat lebih bersifat sosial kemasyarakatan, yang hasilnya tidak langsung terlihat, namun berdampak jangka panjang terhadap reputasi Kebun Raya Eka Karya Bali di mata publik dan terciptanya hubungan baik dengan para stakeholder.

Strategi Komunikasi Pemasaran Terpadu yang dirumuskan oleh Philip Kotler memberi peluang bagi pelaku bisnis dalam hal ini Kebun Raya Eka Karya Bali untuk menciptakan sarana komunikasi yang kreatif dan terjangkau budget, khususnya bagi perusahaan yang memiliki keterbatasan anggaran promosi. Unsur-unsur dalam bauran komunikasi pemasaran ini memberikan pilihan bagi pelaku bisnis untuk menentukan pendekatan mana yang akan digunakan dalam menjangkau publik sasaran. Kreativitas SDM dalam mengemas program komunikasi pemasaran dan perencanaan yang efektif akan berpengaruh pada hasil yang dicapai.

Implementasi strategi komunikasi pemasaran terpadu jasa ekowisata di Kebun Raya Eka Karya Bali memberi dampak yang signifikan terhadap peningkatan minat kunjungan wisatawan ke Kebun Raya Eka Karya Bali dengan rasio kenaikan antara 30.000-80.00o orang pengunjung per tahun.

Ke depan Kebun Raya Eka Karya Bali perlu konsisten menerapkan strategi komunikasi pemasaran terpadu berbasis ekowisata dan perlu ditindaklanjuti dengan proses evaluasi dan monitoring disetiap kegiatan agar terukur efektifitasnya.

\section{Daftar Pustaka}

Alifahmi, Hifni. 2015. Integrating Corporate and Marketing Communications: Delapan Model Kolaborasi Branding, Public Relations, Iklan, Promosi. Jurnal Public relations Indonesia. Jakarta: Bidang Riset dan Kompetensi PERHUMAS Indonesia.

Armstrong, G., Adam, S., Denize, S., \& Kotler, P. 2015. Principles of Marketing, $6^{\text {th }}$ Edition. Melbourne: Pearson Australia Ltd.

Brannan, Tom. 2005. Integrated Marketing Communications. Jakarta: PPM.

Evaluasi Debitur Pariwisata Pasca Bom Kuta dan Jimbaran, www.bi.go.id/NR/ rdonlyres/623C4EA2-D4C7-4CB5-ADCA.../Boks2.pdf, diunduh pada 15 Maret 2013.

Irawan, Handi. 2011. Menjalankan IMC. www.marketing.co.id/2011/o3/18/ menjalankan-imc/imc-1web/ diunduh pada 30 Januari 2016.

marketing.co.id/2012/o1/o2/integrated-marketing-communinations-imc/ $\mathrm{imc/diunduh} \mathrm{pada} 30$ Januari 2016.

Hendarto, Agus K. Bauran Pemasaran Pada Jasa Ekowisata. Jurnal Ilmiah 
Kesatuan Volume 4 Nomor 1 - 2, Pebruari 2003. https://www.facebook.com/ Kebun-Raya-Bali-Bali-Botanic-Garden-139728402772995/?fref=ts. Diunduh pada 30 Januari 2016.

Kotler, Philip. 2009. Manajemen Pemasaran. Jakarta: Erlangga.

Laporan Tahunan Kebun Raya Eka Karya Bali tahun 2010-2015.

Moleong, Lexy J. 2007. Metodologi Penelitian Kualitatif. Bandung: PT Remaja Rosdakarya Offset.

Muhadjir, Noeng. 2002. Metodologi Penelitian Kualitatif. Edisi IV. Yogyakarta: Rake Sarasin.

Salim, A. (2006). Teori \& Paradigma Penelitian Sosial: Buku Sumber Untuk Penelitian Kualitatif Edisi Kedua. Yogyakarta : Tiara Kencana.

Sejarah Kebun Raya Bali, http://www.kebunrayabali.com/id/sejarah.php, Di unduh pada 1 Februari 2016.

Sembiring I., Irfan, H., \& Umar, S. 2004. Survei Potensi Ekowisata di Kabupaten Dairi. http://library.usu.ac.id/download/fp/hutan-iskandar2.pdf. Di unduh 14 Maret 2013.

Shimp, Terence A., \& Andrews, J. C. 2012. Advertising Promotion and Other Aspects of Integrated Marketing Communications. USA: South Western Educational Publishing.

Spillane, J.J. 2001. Ekonomi Pariwisata: Sejarah dan Prospeknya. Yogyakarta: Penerbit Kanisius.

Sulaksana, Uyung. 2003. Integrated Marketing Communications. Yogyakarta: Pustaka Pelajar.

What-is-ecotourism, http://www.ecotourism.org, diunduh pada 14 Maret 2013.

Yin, Robert K. 2008. Case Study Research: Design and Methods (Applied Social Research Methods). Illinois: Sage Publications, Inc.

\section{Profil}

Muntadliroh, S.I.Kom., lahir di Rembang 24 Mei 1984. Sesudah menamatkan pendidikan Diploma III Public Relations Jurusan Komunikasi Fisipol UGM pada 2005, penulis kemudian melanjutkan studi S1 Public Relations di Fakultas Ilmu Komunikasi Universitas Padjadjaran Bandung. Pada tahun 2008 penulis memulai karir sebagai Marketing Communications Officer di salah satu perusahaan swasta nasional. Tahun 2009 menjadi Public Relations Officer di Kebun Raya Bali. Hingga saat ini penulis banyak berkecimpung di bidang Green Public Relations, Ecotourism, Marketing Public Relations dan Pelayanan Publik di Kebun Raya Bali.

Alamat: Candikuning, Baturiti, Tabanan, Bali, 82191. E-mail:mun_tadliroh@yahoo. com,muntoo1@lipi.go.id 